\title{
STATUTORY LIMITATION PERIODS IN ALBERTA STATUTES: 1977 UPDATE
}

In the third issue of its 1974 volume the Alberta Law Review presented the first comprehensive compilation of limitation periods in Alberta statutes done since 1962. The materials presented in the current volume are an effort to continue this project on an annual basis.

The 1974 compilation and subsequent updates were prepared by the Institute of Law Research and Reform at the request of the current editor. The 1976 and 1977 updates have been prepared by the Editorial Board of the Alberta Law Review.

While every effort at thoroughness has been made, the Board does not represent the absolute accuracy or absolute coverage of the limitation periods in the 1976 or 1977 Statutes of Alberta.

It should be noted that no reference has been made to the Alberta Regulations with respect to limitation periods, and the reader is advised to have regard to the provisions of the Interpretation Act, R.S.A. 1970, c. 189 with respect to the computation of time.

Prepared by:

The Editorial Board of the Alberta Law Review

The University of Alberta 


\section{Statute}

The Alberta Income Tax Act, R.S.A. 1970 , c. 182 , as am. by 1977 , c. 74 .

The Alberta Insurance Act, R.S.A. c. 187 as am. by 1977 c. 76 .

The Alberta Uniform Building Standards Act, S.A. 1973 , c. 85 , as am. by 1977 , c. 46.

The Beverage Container Act, 1977 S.A. 1977 , c. 10 (The Beverage Container Act. 1971 repealed).

\section{ACTION OR REMEDY}

s. 8.6(4) A taxpayer is not entitled to a deduction under subsection (1) in respect of a taxation year unless application is made in accordance with the prescribed form of return...

s. 513(2) An applicant who has been refused a certificate of authority or licence to act as an agent, adjuster or broker by the Superintendent or an agent, adjuster or broker whose certificate of authority or licence has been suspended or revoked by the Superintendent may appeal the refusal, suspension or revocation by serving the Minister with a notice of appeal. . .

(3) The Minister shall ... appoint an appeal board to hear the appeal.

(9) A person whose appeal is heard by an appeal board, or the Superintendent, may appeal the decision of the appeal board by filing an originating notice with a court ... and the court may make any order that an appeal board may make under subsection (6).

s. 525.6(1) A person named in an order under section 525.4 (1), other than an interim order. may appeal the order by serving the Minister with a notice of appeal...

(2) The Minister shall, ... appoint an appeal board to hear the appeal.

(7) A person whose appeal is heard by an appeal board, or the Superintendent, may appeal the decision of the appeal board by filing an originating notice with a court. . and the court may make any order that an appeal board may make under subsection (4).

s. 12.1(2) A copy of the orginating notice and each affidavit in support shall be served...

S. 10(2) A person to whom any order under section 7 or 8 is directed may . . appeal to the Minister in accordance with the regulations for any inquiry into the order.

s. 11(2) An appeal under this section shall be commenced by way of originating notice ...

\section{Limitation Period}

within 4 years from the end of that taxation year.

within 30 days of being notified in writing of the refusal, suspension. or revocation.

within 30 days of being served with notice of appeal under ss. (2).

within 30 days of being notified in writing of the decision.

within 30 days of being served with the order.

within 30 days of being served with a notice of appeal under ss. (1),

within in $\mathbf{3 0}$ days of being notified in writing of the decision.

not less than 3 days before the day named in the notice for the hearing or such shorter time as the Court may direct.

within 15 days after service upon him of the order.

within 30 days from the date that the notice under s. $10(5)(b)$ is served upon the person appealing the decision of the Minister. 
The Child Welfare Act, R.S.A. 1970, c. 45 as am. by 1977. c. 11 .
The Companies Act, R.S.A. 1970 , c. 60 , as am. by 1977 , c. 13. s. 95(1) The Director shall send a copy of each certificate issued under this Part to a clerk of the juvenile court. . .

s. 96(3) The clerk shall give notice of the nature, time and place of any hearing under this Part by registered mail or by any other method authorized by a judge to

(a) the Director.

(b) the child, his parent or parents and his representative, if any.

(c) the person in charge of the institution in which the child is being confined, and

(d) any other person that the judge considers may be affected by the application and should be notified ...

s. 96(5) The hearing shall be held...

(a) a direction of a judge under section 95 , or

(b) an application being made under this section.

s. $98(1) \ldots$

(a) the child, his parent or parents, or his representative, if any, or

(b) the Director.

may appeal to the Supreme Court by filing with the clerk of the Supreme Court of the judicial district within which the order was made a notice of appeal setting out the particulars of the order appealed from and the grounds of the appeal.

(2) A copy of the notice of appeal shall be served upon the clerk of the juvenile court which made the order and

(a) upon the child, his parent or parents or his representative, if any, or

(b) upon the Director, as the case may be....

(3) The clerk of the juvenile court which the order appealed from shall ... forward to the clerk of the Supreme Court of the judicial district in which the notice of appeal is filed.

(a) the order,

(b) the depositions or transcript of the evidence taken at the hearing, and

(c) all documents and exhibits filed at the hearing.

s. 41.21(5) An action to enforce a liability under subsection (1) may be commenced ...

s. 41.3 A private company that purchases shares issued by it shall notify the Registrar ... of the date, the number and the class or kind of shares that it has purchased.

s. 41.31(3) An action to enforce any right created by subsection (2) may be commenced within 48 hours of issuing the certificate.

at least five days before the date fixed for the hearing.

within 14 days... or within such further period as a judge may direcl.

within 30 days from the day on which a judge of the juvenile court makes an order under s. 97.

within 30 days from the date of making the order, or such longer time as a judge of the Supreme Court may order.

within 7 days from the time the notice of appeal was served upon him.

only within two years after the date of completion of the purchase.

within 30 days of the date purchase.

only within two years after the date of completion of the purchase. 
The Companies Act, R.S.A. 1970 , c. 60 , as am. by 1977 , c. 13 . (con't.).

The County Act, R.S.A. 1970 , c. 71 , as am. by 1977 , c. 14 .

The Department of Housing and Public Works Act, S.A.

$1975(2)$, c. 13 , as am. by 1977 , c. 56 .

The Department of Transportation Act, S.A. $1975(2)$, c. 17 , as am. by 1977 , c. 56 .

The Domestic

Relations Act, R.S.A. 1970 , c. 113 , as am. by 1977, c. 64 . s. 41.4(1) Unless all of the shareholders at the date of the purchase have unanimously agreed in writing to the proposed purchase. a company that proposes to purchase shares issued by it shall

(c) in the case of a private company, file a copy of the offering circular with the Registrar...

$$
\text { and }
$$

(d) in the case of a public company, file a copy of the offering circular with the Commission...

s. 6(2) repealed.

The Schedule is amended as to Form 1, by striking out the words ". . at least 10 per cent of the proprietary electors of the County petition the council to conduct a plebiscite" and by substituting therefor the words the electors of the County equalling not less than 5 per cent of the population of the County as determined under section 6, subsection (4) of The County Act petition the council to conduct a vote."

s. 16(1) the Minister shall

(a) cause to be prepared a balance sheet and and statement of operations of the re. volving fund for the immediately preceding fiscal year.

(b) submit the financial statement to the Auditor General.

s. $13(1) \ldots$ the Minister shall

(a) cause to be prepared a balance sheet and statement of operations of the revolving fund for the immediately preceding fiscal year, and

(b) submit the financial statements to the Auditor General.

s. 28.3(7) A copy of the order shall be served on the respondent not later than...

s. $28.3(11) \ldots$ the debtor shall either

(a) pay to the clerk of the Family Court the lesser of

(i) the money due from him to the person ordered to pay maintenance or alimony, and

(ii) an amount sufficient to satisfy the order and any costs fixed in the order by the judge.

(b) file an answer in the office of the clerk of the Family Court stating that the money is accruing due but is not yet payable and that it is to be payable at a specified future date or upon the happening of a specified event, within 15 days of the date that it is first delivered or mailed to the shareholders of the company.

within 5 days of the date that it is first delivered or mailed to the shareholders resident in Canada.

within 30 days from the first publication of this Notice.

on or before June 15 in each year.

on or before June 15 in each year.

20 days after payment by the debtor to the clerk of the Family Court.

within 10 days after service of the order on the debtor. 
The Domestic Relations Act, R.S.A. 1970, c.113, as am. by 1977 , c. 64 . (con't.).
The Election Act, R.S.A. 1970 , c. 117 as am. by 1977 , c. 17 . (c) file an answer in the office of the clerk of the Family Court disputing his liability to the person ordered to pay maintenance or alimony, or

(d) file an answer in the office of the clerk of the Family Court that the debt attached belongs or may belong to some third person whose name and address so far as is known to the debtor shall be stated.

s. 28.3(17) The notice of motion shall be served on the clerk of the Family Court that issued the original attachment order, the respondent, the debtor and any other person claiming to be interested in the money attached not less than...

s. 2.2(4) If an appointment under subsection (3) is not confirmed . . . the appointment lapses and there shall be deemed to be another vacancy in the office of the Chief Electoral Officer.

s. 15(b) ... each returning officer shall sub. divide the electoral subdivision for which he was appointed into as many polling sub. divisions as he considers necessary for the convenience of the voters, ensuring that each part of the electoral division is included in a polling subdivision;

s. 15.1(3) . . the Chief Electoral Officer shall ensure that each returning officer has a sufficient supply of badges for each enum. erator within the electoral division for which he was appointed.

s. 20.1(1) The Chief Electoral Officer shall ... provide to each returning officer a list containing the names and addresses of each registered party under The Election Finances and Contributions Disclosure Act of record on November 1 of that year and the name and address of each member of the Legislative Assembly who is not a member of a reg. istered party.

(2) . . each returning officer shall furnish free of charge 10 copies of the list certified by him pursuant to section 23.1 to each registered party under The Election Finances and Contribution Disclosure Act and one copy to each member of the Legislative assembly who is not a member of a registered party in accordance with the list provided to him by the Chief Electoral Officer.
15 days before the date on which the application is to be heard.

within 30 days after the commencement of the next ensuing regular sitting.

on the 15th day of August in the second calendar year follow. ing the year in which the last general election was held and on the 15th day of August in each succeeding year if no general election is held in the interim,

Prior to the 15th day of August in the second calendar year following the year in which the last general election was held, and prior to the 15th day of August in each succeeding year if no general election is held in the interim.

not later than November 30 in each enumeration year.

not later than February 1 of the year following a general enumeration. 
The Election Act, R.S.A. 1970 , c. 117 as am. by 1977 , c. 17 . (con't.).

The Election

Finances and Contributions Disclosure Act, S.A. 1977, c. 18. s. 24(1.1) The period for further revision of the list pursuant to subsection (1) shall commence .... and continue each day except Sunday concluding

s. 161.(1) A detailed statement of all election expenses incurred by or on behalf of a candidate including personal expenses under section 158 shall ... be made out in Form 48 , signed by the chief financial officer of the candidate or by the official agent of any candidate other than a registered candidate under The Election Finances and Contribution Disclosure Act and delivered to the returning officer together with the bills and vouchers relating thereto.

s. 2(3)(d) shall file with the Chief Electoral Officer ... a report of the expenditures or transfers from the trust during the previous year and a statutory declaration of compliance with the provisions of $(b)$ and $(c)$...

s. 4(3) Any information with respect to the affairs of a registered party, registered constituency association or registered candidate that is reasonably required by the Chief Electoral Officer in the course of his duties under this Act shall be provided by the registered party, constituency association or candidate...

s. 5(6) Each foundation shall file with the Chief Electoral Officer on or before the ... a report of the expenditures of that foundation during the previous year.

s. 6(4) Where there is any change in the information required to be provided by subsection (1), clauses (a) to (i), the registered party shall notify the Chief Electoral Officer in writing ... and, subject to section 10 , upon receipt of the notice the Chief Electoral Officer shall vary the register of political parties accordingly.

s. $7(4)$ Where there is any change in the information required to be provided in subsection (2), clauses (a) to (f), the registered constituency association shall notify the Chief Electoral Officer in writing ... and, subject to section 10 , upon receipt of any such notice the Chief Electoral Officer shall vary the register of constituency associations accordingly.
4 clear days after the issue of the writ of election

3 clear days prior to the first day upon which voting may commence at advance polling places.

within 6 months after polling day,

on or before the 1st day of April next following the commencement of this section and on or before the lst day of April in each year thereafter,

within 30 days after receiving a written request therefor from the Chief Electoral Officer or within such extended period as the Chief Electoral Officer may determine.

on or before the 1st day of April next following the commencement of this section and on or before the 1st day of April in each year thereafter,

within 30 days of the alteration

within 60 days of any such alteration 
Election Finances (con't.). s. 9(5) Where there is any change in the information required to be provided in sub section (2), clauses (a) to (g); the registered candidate shall notify the Chief Electoral Officer in writing . ... and, subject to section 10 , upon receipt of any such notice the Chief Electoral Officer shall vary the register of candidates accordingly.

s. 10(6) A political party, constituency association or candidate notified under subsection (5) may ... request the Chief Elec toral Officer in writing to review the cancellation.

(7) Where the Chief Electoral Officer receives a written request under subsection (6), he shall ... review the cancellation and give the political party, constituency association or candidate concerned an opportunity to make representations.

s. 12(2) Where a person referred to in sub section (1) is nominated or, in the case of an independent candidate, declares himself to be a candidate, for the general election next succeeding the commencement of this section or at an intervening by-election, he shall, if the amount held in trust exceeds $\$ 2,500$.

(a) ... report in writing to the Chief Elec toral Officer the existence of the trust.

(d) file with the Chief Electoral Officer... a report on the expenditures or trans fers from the trust during the campaign period and a statutory declaration of compliance with clause (b) and (c), and

(3) When a person referred to in subsection (1) is not nominated or does not declare himself to be an independent candidate for the general election next succeeding the commencement of this Act, he shall. . transfer or pay the amount held by him in trust pursuant to subsection (1) to ...

s. 13(2) When a person referred to in subsection (1) is not nominated or does not declare himself to be an independent can. didate for the general election next succeed. ing the commencement of this section, he shall, . . . transfer or pay the amount held by him in trust pursuant to subsection (1) to ...

s. $18(2)$ Where the chief financial officer learns that any contribution was accepted by or on behalf of the registered party. registered constituency association or re. gistered candidate for whom he acts in excess of the limits imposed by section 17 , he shall . . advise the Chief Electoral Officer in writing of the fact and circumstances.

s. 3013) Where the chief financial officer learns that any contributions received by or on behalf of the registered party, registered constituency association or registered can. didate for whom he acts was made contrary to subsection (1), he shall ... advise the Chief Electoral Officer in writing of the fact and circumstances. within 60 days of any such alteration

within 30 days after the mailing of the notice,

within 48 hours thereafter.

within 7 days

not later than 6 months after polling day

not later than 7 days after the day fixed for nominations

not later than 7 days afte the day fixed for nomination

within 30 days after learning thereof,

within 30 days after learning that the contribution was made contrary to subsection (1), 
Election Finances (cont.). s. $31(3)$ Where the chief financial officer learns that any contribution was accepted by or on behalf of the political party. constituency association or candidate for whom he acts from any person normally resident outside Alberta or from any corporation that does not carry on business in Alberta. or from any trade union or employee organization as defined in this Act, he shall... advise the Chief Electoral Officer in writing of the fact and circumstances.

s. 36(1) The chief financial officer of every registered party and registered constituency association shall . . . file with the Chief Electoral Officer financial statements of assets and liabilities and of receipts and payments or transfers for the previous year of the political party or constituency association for which he acts, excluding campaign receipts and payments or transfers relating to an election during a campaign period.

s. 37(1) The chief financial officer of every registered party, registered constituency association and registered candidate shall ... file, with the Chief Electoral Officer a financial statement of receipts and payments or transfers of the political party, constituency association or candidate for which he acts relating to the election during the campaign period.

s. $38(2)$ Where a registered candidate who was declared elected remains ineligible to sit or vote in the Assembly pursuant to subsection (1)... the seat of that registered candidate, subject to subsection (3), thereupon becomes vacant.

(3) A registered candidate who was declared elected may ... a apply to the Supreme Court of Alberta for relief and the Court may

(a) dispense with compliance with section 37 if it considers that the non-compliance is due to circumstances beyond the control of the candidate, or

(b) extend the time for compliance with with section 37 where it finds mitigrating reasons for non-compliance with that section but

(j) during the extended period of time the candidate remains ineligible to sit or vote in the Assembly, and

(ii) the seat of the candidate becomes vacant if he fails to comply with that section within the extended period of time or such additional extended periods of lime as the Court may be order allow, or

(c) declare the candidate not to be ineligible to sit or vote by reason of non-compliance with section 37 if it is satisfied that, at the time of the application, the necessary financial statement has been filed, or

(d) refuse the application. within 30 days after learning thereof,

on or before the 31st day of March next following the commencement of this section and on or before the 31st day of March in each year thereafter.

within 6 months after polling day,

for a period of 60 days,

at any time not exceeding 60 days after the Speaker tables the report of the Chief Electoral Officer under subsection (1). 
The Farm Implement Act, R.S.A. 1970 . c. 136 , as am. by 1977 , c. 67 .

The Legal Profession Act, R.S.A. 1970 , c. 203 , as am. by 1977 , c. 55.

The Licensing of Trades and Businesses Act, R.S.A. 1970 , c. 207 , as am. by 1977, c. 59 . s. 6(1) Where a new farm implement used under reasonable operating conditions and with proper use and maintenance fails to perform the work for which it is intended in a satisfactory manner during

(a) any of the first $\mathbf{1 0}$ days of actual use of the farm implement, whether or not those days are consecutive, or

(b) the first 100 hours of actual use of the farm implement, whether or not that period is continuous,

from the time the implement is first used within the first normal season of use after the implement is delivered to the purchaser. whichever period occurs first, the purchaser may give notice within that season by registered mail to the distributor, the dealer and the Minister of the farm implement's failure to perform that work.

(1.1) Upon receiving notice under subsection

(1), the dealer or distributor shall

(a) not later than 7 days after the date on which he received the notice, if reasonable operating conditions exist for that farm implement during that 7-day period, or

(b) not later than 7 days during which reasonable operating conditions exist for that farm implement after the date on which he received the notice.

endeavour to make the farm implement perform in a satisfactory manner.

(1.2) Where a dealer or distributor fails to make the farm implement perform in a sat. isfactory manner pursuant to subsection (1.1), the dealer or distributor shall . . . provide the purchaser with a satisfactory substitute farm implement for the purchaser's use until his implement is made to perform in a satisfactory manner.

s. 73(5) A member to whom subsection (4) applies shall be struck off the roll ... if he has not in the interim become a Canadian citizen.

s. 8.1(2) The Minister shall ... appoint an appeal board to hear the appeal.

(8) The Director or a person whose appeal is heard by an appeal board may appeal the decision of the appeal board by filing an originating notice with the Supreme Court of Alberta. . . and the Court may make any order that an appeal board may make under subsection (4). [the first 10 days or 100 hours of actual use]

not later than 7 days [after notice and during which reasonable operating conditions exist]

within 48 hours after the period stated in s.s.(1.1),

at the expiry of 5 years from the date he ceased to be a British subject

within 30 days of being served with a notice of appeal under subsection (1).

within 30 days of being notified in writing of the decision. 
Mobile Equipment Licensing Act, R.S.A. 1970 , c. 241 , as am. by 1977 , c. 29 .

The Mortgage Brokers Regulation Act, R.S.A. 1970 , c. 242 , as am. by 1977 , c. 59

The Motor

Transport Act, S.A. 1977 , c. 80 . s. 11(1) Where a person acquires a licence for mobile equipment, he shall

(b) ... forward to the Minister, on the form prescribed by the Minister, a re. turn stating the municipalities in which the mobile equipment was located in the year in which the licence was issued and the number of days that mobile equipment was located in each of those municipalities in that year.

s. 24(1) A person upon whom a notice is served under section 23 may appeal the direction, decision, order or ruling of the Superintendent by serving the Minister with a notice of appeal...

s. 24(2) The Minister shall . . appoint an appeal board to hear the appeal.

s. 24(7) A person whose appeal is heard by an appeal board, or the Superintendent, may appeal the decision of the appeal board by filing an originating notice with the Supreme Court of Alberta .... and the Court may make any order that an appeal board may make under subsection (4).

s. 23 Where new evidence concerning a matter is submitted to the Board ... the Board may

(a) reconsider the matter or reopen any hearing on the matter, and

(b) rescind, vary, affirm or make its decision on the basis of all evidence before it,

unless an appeal has been commenced pursuant to section 29 .

s. 24(2) Where the Board proposes to sus. pend, revoke or amend a certificate pursuant to subsection (1), it shall provide to the holder by registered mail ... notice of its proposed action and the reason for it.

s. $47(4)$. . the insurer or the guarantor under a bond shall notify the Board of the impending cancellation or termination, and in the absence of any such notice the policy or bond, as the case may be, remains in full force and effect until the required 15 days notice has been given.

s. 53(4) A person who carries on business as a liveryman in a city or town shall .. . deliver to the mayor of the city or town a list of operators employed by him as of the last day of the preceding month. before February 1 immediately following the year in which the licence was issued,

within 30 days of being served with notice of the direction, decision, order or ruling.

within 30 days of being served with a notice of appeal under subsection (1),

within 30 days of being notified in writing of the decision.

either within $\mathbf{3 0}$ days after the Board has made a determination, within 30 days after the Board has sent notification to all parties of its determination,

not less than 10 days

at least 15 days before the date of a cancellation or expiration of any insurance policy or bond required under this Act or any orders made under this Act.

not later than the 3rd day of each month. 
The Municipal

Election Act. R.S.A 1970 , c. 245 , as am. by 1977 , c. 31 . s. $41(2)(a)$ registration shall take place.

$(i)$ in the case of a general election ...

(ii) in the case of a vote on a question or bylaw that is not being held in conjunction with a general election...

s. 311(2) Notice of the proposed by-law shall be given once a week for two consecutive weeks in a newspaper circulating in the municipality ... by 1977 , c. 83 .

\section{The Nursing} Assistants Registration Act, S.A. 1977 , c. 85 . s. 8(1) A person who is refused registration pursuant to section 6(3) may apply for a review of the Board's direction by an application in writing to the Minister made ...

s. 10(5) A copy of the complaint and the decision of the Board under subsection (3) shall be served by registered mail on the registered nursing assistant ...

s. 10(6) Notice of the date of any hearing shall be served by registered mail on the registered nursing assistant concerned and on the complainant...

s. 11(1) A registered nursing assistant against whom an order has been made under section 10(9) may ... appeal to the District Court by way of originating notice.

s. 11(2) The originating notice shall

(a) name the Board as the respondent, and

(b) be served on the Registrar ...
The Nursing Homes Act, R.S.A. 1970, c. 264 , as am. by 1977 , c. 35 .
The Petroleum Marketing Act, S.A. 1973 , c. 96 , as am. by 1977 . c.88. s. 11.3(7) An official administrator shall ... give to the operator of a contract nursing home under his administration a written statement in a form prescribed by the Minister setting forth the financial transactions relating to the contract nursing home undertaken by the administrator during that month.

s. 29(2) The lessee or his agent shall furnish to the Commission a copy of each report respecting the amount of pentanes plus re. covered that the lessee is required to file under section 135 of The Mines and Minerals Act, within the same period of time as that required under that section for filing with the Department. in the period from January 1 to the seventh day following nomination day in the year that the general election is held,

not less than 21 days prior to the date fixed for voting on the question or by-law.

within 60 days from the date of the issuance of an order or other authoriza. tion by the local Authorities Board approving a by-law.

within 30 days after the date of the direction of the Board.

within $\mathbf{1 5}$ days after the decision is made.

at least 30 days before the date set for a hearing under this section.

within $\mathbf{3 0}$ days of the date of service on the nursing assistant.

within 30 days from the date of service of the order on the registered nursing assistant.

within 15 days of the end of each month.

[within the period of time required by s.135 of the Mines and Minerals Act] 
The Planning Act, 1977 S.A. 1977 , c. 89. s. 7(1) If anything to be done by a council, person or body of persons, within a number of days or at a time fixed by or under this Act or the regulations, cannot be or is not so done, the Minister may by regulation form time to time appoint a further or other time for doing it, whether the time at or with. in which it ought to have been done has or has not arrived or expired, as the case may be.

s. 11(1) The Board shall notify each council by ... of the amount the council is required to pay into the Alberta Planning Fund.

(2) Each council shall pay the amount required of it on or before...

s. 43(4) A copy of the originating notice and a copy of each affidavit in support shall be served...

s. $49(2)$ The regional planning commission shall give ... notice in writing to every local authority in the planning region of its in. tention.

(a) to consider the adoption of the proposed regional plan as the regional plan, or

(b) to consider the adoption of an amendment to the regional plan,

s. 55(3) An appeal shall be made...

s. 5611) The Board shall hold a public hearing on the appeal after giving ... notice to

(a) the appellant

(b) the council of each municipality in the planning region,

(c) every other local authority whose powers extend to the planning region. and

(d) such other persons or organizations as the board considers necessary.

s. 70(1) If land is designated under a land use by-law for use or intended use as a municipal public building, school facility, park or recreation facility and the municipal corporation does not own the land, the council shall

(a) ...

(i) acquire the land or require it to be provided as reserve land pursuant to this Act, or

(ii) amend the land use by-law to designate the land for another use or intended use. [please note]

by May 1 of each year, or as soon thereafter as possible.

on or before June 1 of each year or within 30 days of the Board's notification under s.s. (1), whichever last occurs.

not less than three days before the day named in the notice for hearing the application.

at least 30 days'

within 60 days of the date of the decision appealed.

at least 10 days'

within 6 months from the date the land is so designated

or 
The Planning Act 1977 (con't.) (b) ... commence proceedings to acquire the land or require it to be provided as reserve land and thereafter acquire it within a reasonable time.

(2) Notwithstanding subsection (1), if the Crown in right of Canada, the Crown in right of Alberta or another local authority ...

(a) acquires the land, or

(b) commences proceedings to acquire the land or requires it to be provided as reserve land and thereafter acquires it within a reasonable time, subsection (1) does not apply.

s. 81(2) An application for a development permit shall, at the option of the applicant, be deemed to be refused when the decision of a development officer is not made .. .

s. 82(1) A person referred to in section 81 , subsection (3) or any other person affected by an order, decision or development permit of a development officer may appeal to a development appeal board by serving a written notice of the appeal on the development appeal board ...

(2) ... the development appeal board shall hold a public hearing respecting the appeal.

(3) The development appeal board shall give ... notice in writing of the public hearing to

(a) the appellant,

(b) the development officer from whose order, decision or development permit the appeal is made,

(c) the municipal planning commission of the municipality if it is not the develop. ment officer, and

(d) those owners required to be notified under the land use by-law and any other person that the development appeal board considers to be affected by the appeal and should be notified.

s. 83(2) The development appeal board shall

(a) make and keep a written record of its proceedings, which may be in the form of a summary of the evidence presented to it at the hearing, and

(b) give its decision in writing together with reasons for the decision...

s. $102(1) \ldots$ the applicant shall submit to the subdivision approving authority

(a) a plan of subdivision, or

(b) any other instrument.

together with a statutory declaration that all the conditions attached to the subdivision approval have been met or an undertaking that they will be met.

(4) If the plan of subdivision or other instrument is not submitted to the subdivision approving authority within the time prescribed by subsection (1) or such longer period as may be authorized by the subdivision approving authority, the subdivision approval is void. within 6 months from the date the land is do designated

within 6 months from the date the land referred to in subsection (1) is designated as described in that subsection

within $\mathbf{4 0}$ days of receipt of the application.

within 14 days after the date the order, decision or develop. ment permit was issued.

Within 30 days of receipt of notice of appeal.

at least 5 days'

within 15 days of the conclusion of the hearing.

within two years of the date on which an application for subdivision approval is approved or such longer period as may be authorized by the subdivision approving authority. 
The Planning Act (con't). s. 103(1) An appeal from a subdivision

The Public Service Employee Relations Act, S.A. 1977, c. 40. approving authority or a condition imposed by it under this Act or the regulations may be commenced ... . by filing a written notice of the appeal with the Board ...

(2) Where a subdivision approving authority fails or refuses to make a decision on an application for subdivision approval within the time prescribed by the regulations, the applicant may ...

(a) treat the application as refused and appeal to the Board by notice in writing. or

(b) enter into an agreement with the sub. division approving authority to extend the time prescribed in the regulations.

(3) Where an agreement to extend is entered into pursuant to subsection (2), clause (b) and the subdivision approving authority fails or refuses to make a decision within the time prescribed in the agreement, the applicant may ... treat the application as refused and appeal to the Board by notice in writing.

s. 132(1) A registered owner of land included in a replotting scheme may ... a apply to the Land Compensation Board to determine replot compensation.

(2) The Land Compensation Board shall

(a) fix a date, time and place for the hearing of an application referred to in subsection (1), and

(b) cause a notice in writing to be served on the applicant and the council ...

s. 139 A by-law passed pursuant to this Act is valid and binding notwithstanding any lack of compliance with a provision of this Act or The Municipal Government Act.

(a) either in substance or in form, or

(b) in the proceedings prior to the passing of the by-law, or

(c) in the manner of passing the by-law, unless an application to quash it is made ...

s. 146(1) Subject to subsection (2), upon a question of law or upon a question of juris diction, an appeal lies to the Appellate Division of the Supreme Court of Alberta from the Board or a development appeal board.

(2) An application for leave to appeal pur suant to subsection (1) shall be made

(a) to a judge of the Appellate Division, and

(b) ...

within 30 days of the date of the receipt of the approval, order, or decision of the subdivision approving authority. within 30 days of the expiration of the time prescribed.

within 30 days of the expiration of the extended period,

not later than 3 months after the date of registration of the plan of subdivision relating to the scheme by the council pursuant to s. 129 ,

not later than 30 days before the date fixed for the hearing.

within 2 months next after the final passing of the by-law.

within 30 days after the issue of the order, decision, permit or approval sought to be appealed.

within $\mathbf{3 0}$ days of s. 12(2) Any changes to the information supplied under subsection (1) shall be given to the Board ... the date the change is made. 
The Public Service Employee Relations Act, S.A. 1977 , c. 40 . (con't.). s. 24. An application to the Board to be included in or excluded from a bargaining unit or any other unit for collective bargaining under section 22 or 23 may be made

(a) if a collective agreement for a term of two years or less is in force in respect of any of the employees of the employer ... affecting the unit in respect of which the application is made, or

(b) if a collective agreement for a term of more than two years is in force in respect of any of the employees of the employer, at any time ... . of the collective agreement affecting the unit in respect of which the application is made.

s. 26. An application by a trade union to be certified as the bargaining agent of employees in a unit may be made

(a) if no collective agreement and no certification of a bargaining agent is in effect in respect of any of the employees in the unit, at any time;

(b) if no collective agreement is in force and a bargaining agent has been certified in respect of any of the employees in the unit ...

(c) if the certification of a bargaining agent in respect of any of the employees in the unit is questioned or reviewed by the Court .... unless the Court quashes the decision of the Board to certify the bargaining agent;

(d) if a collective agreement for a term of two years or less is in force in respect of any of the employees in the unit ...

(e) if a collective agreement for a term of more than two years in in force in respect of any of the employees in the unit, at any time...

s. 32(2) An application under subsection (1) may be made.

(a) if no collective agreement is in force...

(b) if the certification of a bargaining agent is questioned or reviewed by the Court . . unless the Court quashes the decision of the Board to certify the bargaining agent; at any lime in the two months prior to the end of the term of the collective agreement

in the 11th or 12th month of the second year or the 11 th or 12 th month of any subsequent year of the term, or in the two months prior to the end of the term.

at any time after the expiration of 10 months from the date of certification of the bargaining agent;

at any time after the expiration of 10 months from the date of final disposition of the question or review,

at any time in the two months prior to the end of the term of the collective agreement

in the $11 \mathrm{th}$ or $12 \mathrm{th}$ month of the second year or the 11th or 12th month of any subsequent year of the term, or in the two months prior to the end of the term.

at any time after the expiration of 10 months from the date of certification of the bargaining agent;

at any time after the expiration of 10 months from the date of final disposition of the question or review, 
Public Service (con't.). (c) if a collective agreement for a term of two years or less in in force,...

(d) if a collective agreement for a term of more than two years is in force...

(3) An employer may apply to the Board to revoke the certification of a bargaining agent but only if the employer and the certified bargaining agent have not bargained collectively for a period of ...

(a).... if no collective agreement has been entered into affecting the employer and the certified bargaining agent,

(b) ... if a collective agreement has been entered into between the employer and the certified bargaining agent.

s. 34(2) An application under subsection (1) may be made

(a) if a collective agreement for a term of two years or less is in force...

(b) if a collective agreement for a term of more than two years is in force...

s. 38(2) Where a collective agreement is in effect, either party to the collective agreement may ... by notice in writing, require the other party to the collective agreement to commence collective bargaining.

s. 39(1) A notice to commence collective bargaining shall be served...

(3) Upon the service of a notice to commence collective bargaining, the bargaining agent and the employer, without delay but in any event... shall

(a) meet and commence or cause authorized representatives to meet and commence to bargain collectively in good faith, and

(b) make every reasonable effort to enter into a collective agreement. at any time in the two months prior to the end of the term of the collective agreement:

at any time in the 11 th or 12 th month of the second year or in the 11th or 12 th month of any subsequent year of the term, or in the two months prior to the end of the term.

three years from the date the trade union became the certified bargaining agent .... or from the first fixed date for the termination of the collective agreement.

at any time in the two months prior to the end of the term of the collective agreement.

at any time in the 11 th or 12 th month of the second year or the 11th or 12 th month of any subsequent year of the term, or in the two months prior to the end of the term.

not less than 30 days and not more than 90 days preceding the expiry of the term or within such longer period as may be provided for in the collective agreement,

at least 10 days before the time fixed in the notice for the commencement of collective bargaining. within 20 days after the notice is given. 
Public Service (con't.).

Public Service Management pension Act, S.A. 1972, c. 81 , as am. by 1977 , c. 87.

Public Service Pension Act, R.S.A. 1970 , c. 299 , as am. by 1977 , c. 87 .

The Rent Decontrol Act, S.A. 1977, c. 41 . s. $47(3)$... the mediator shall report to the Board whether the parties were able to resolve the dispute.

s. $49(4)$ The party receiving the copy of the request for the appointment of an arbitration board shall ... and if the party has additional arbitral items to add, send those items to the Board and send a copy of them to the other party to the dispute.

s. 51(1) Where the Board agrees to establish an arbitration board, it shall notify the parties to the dispute in writing accordingly and require each of them ... to appoint a person to act as a member of the arbitration board.

(2) The two persons appointed to act as members of an arbitration board shall appoint a third person to act as a member and chairman of the arbitration board...

s. 63(f) Upon receipt of a notice referred to in clause (c), subclause (ii) or a notice referred to in clause (e), subclause (ii) indicating that the party sending the notice wishes as adjudication board to be established, the recipient of the notice shall ... notify the other party of the name of its appointee to the adjudication board.

(g) Upon the appointment of two appointees to an adjudication board they shall ... appoint a third person as a member who shall be chairman.

s. 89(2) Notwithstanding subsection (1), the award, proceeding or decision of a tribunal may be questioned, or reviewed by way of an application for certiorari or mandamus, if an application therefore is filed with the Court...

s. 15(4) Notwithstanding subsection (1), where

(c) an employee

(ii) has made arrangements for payment with respect to his prior service that are satisfactory to the Board ... subsection (1)(e) does not apply.

s. 14(5) Notwithstanding subsection (1), where

(c) an employee

(ii) has made arrangements for payment with respect to his prior service that are satisfactory to the Board ...

subsection (1)(e) does not apply.

s. 6. A landlord shall, with respect to any residential premises rented by him under a tenancy agreement under which the tenancy commences on July 1,1977 or any subsequent date, notify the tenant thereof in writing of the base rent of the residential premises
Within 20 days of the date of his appointment or such longer period as the parties agree, within 10 days of receipt of copy [of request for the appointment of an arbitration board]

within 10 days [of notice]

within 10 days of the date the second person is appointed.

within seven days [of notice]

within seven days of the appointment of the second of them,

not later than 30 days after the date of the award, proceedings or decision of the tribunal.

within 90 days of being so advised by the Board,

within 90 days of being so advised by the Board,

within 10 days of the tenant taking possession of the premises. 
Rent Decontrol (con't.). s. 7(4) Where a landlord of residential premises wishes to make a permitted increase and the premises are vacant or will become vacant by reason of a landlord having given notice of termination of tenancy, the landlord shall give to a rent regulation officer a written notice of the increase in the rental rate...

s. 8(2) An application under subsection (1) shall

(c) be made...

s. 10(1) A tenant of residential premises may, ... file a written statement of interest with a rent regulation officer and shall, at the same time, give a copy of the statement of interest to the landlord of the residential premises.

s. 11(1) The rent regulation officer shall ... consider the application and any statement of interest filed.

s. 13(4) No application may be made by a tenant under this section with respect to any reduction or cessation of service or increase or demand for consideration by a landlord. . .

s. 27(1) A landlord or a tenant may. . . appeal to the Board by filing a written notice of the appeal with the Board.

s. 28(1) ... a landlord or a tenant affected thereby may file with the Board written arguments with respect to the report and the recommendations or either of them.

s. 39 Notwithstanding anything to the contrary in The Landlord and Tenant Act or in any agreement, where

(a) a landlord of a mobile home site in a mobile home park gives to the tenant a notice of termination of the tenancy,

(b) the sole or principal reason for giving the notice of termination is to enable the landlord to obtain vacant possession of the mobile home site in order to use it otherwise than as a mobile home site, and

(c) the giving of the notice of termination is part of a plan or scheme of the landlord to obtain vacant possession of all the mobile home sites in the same mobile home park in order to use them otherwise than as mobile home sites,

the notice of termination of tenancy shall be for a period of ... at least 90 days before the date on which the increase is to be effective.

at least 90 days before the increase is proposed to be effective.

within 15 days of his receipt of a copy of the landlos applica. tion for a greater increase in the rental rate than the permitted increase,

within 60 days of his receipt of an application by a landlord under s. 8 ,

after June 30, 1980.

within 15 days of the date of an order of a rent regulation officer under s. 11 or s. 15 .

within 10 days of the date that a report and recommendations are sent to the Board pursuant to section 14 ,

not less than one year from the date on which it is given to the tenant. 
The School Act, R.S.A. 1970 , c. 329 as am. by 1977 , c. 42 .

The Social Care Facilities Act, S.A. 1977 , c. 91.

The Social Develop. ment Act, R.S.A. 1970 , c. 345 as am. by 1977 , c. 92 .

The Societies Act, R.S.A. 1970 , c. 347 , as am. by 1977 , c. 59 . s. $75(3)$ Where a teacher is given a notice of transfer, that teacher may .. make a written request to the board to have a hear. ing before the board for the purpose of objecting to the transfer.

s. $81(1)$ Where the Director is of the opinion that

(a) a licence holder is not providing proper care to a person accommodated or cared for in his social care facility,

(b) the premises described in the licence have become unfit or unsuitable for the purpose authorized by the licence.

(c) the number of persons accommodated or cared for in the social care facility exceeds the number specified in its licence, or

(d) a licence holder has not complied with the provisions of

(i) this Act or the regulations,

(ii) a conditional licence.

(iii) an order made under section 7, or

(iv) any other Act or regulation that applies to a social care facility.

the Director may ... cancel or suspend the licence.

s. 9(1) A person

(a) who has been refused a licence under section $5(2)$, or

(b) whose licence has been cancelled or suspended under section 8 ,

may appeal the refusal, cancellation or suspension by serving the Minister with a notice of appeal ...

(2) The Minister shall . . . appoint an appeal board to hear the appeal.

(8) The Director or the person whose appeal is heard by an appeal board may appeal the decision of the appeal board by filing an originating notice with the Supreme Court of Alberta ... and the Court may make an order that an appeal board may make under subsection (4).

s. 12.2 Where a person has received a social allowance and applies for the issue of a summons pursuant to section 28 of The Domestic Relations Act that person shall notify the Minister of the issuance of the summons...

24(2) Notice of the location of the registered office of a society, giving the postal address. shall be filed with the Registrar

(b)...

s. 25(2) A society shall each year . . make a return to the Registrar within 7 days of receiving the notice of transfer,

on 30 days' notice in writing to the license holder,

within 30 days of being notified in writing of the refusal, cancellation or suspension.

within 30 days of being served with the notice of appeal, within 30 day of being served with the order made under subsection (4)

not less than 10 days before the date on which the summons is returnable.

within 15 days of a change in the location of the registered office.

on or before the last day of the month immediately following its anniversary month, 
Tax Recovery Act, 1922 , c. 162 , repealed by 1977 , c. 95 .

The Trust Com. panies Act, R.S.A. 1970 , c. 372 , as am. by 1977, c. 98 .
Vital Statistics

Act, R.S.A. 1970 , as am. by 1977 c. 48 . s. 132(2) A person is not liable under subsection (1)

(a) if, being a director when the unauth orized investment or loan was approved and being present at the meeting of the board of directors or a committee thereof at the time when it was approved, he (ii) notified the Director, in writing, of his protest...

(b) if, being a director when the unauthorized investment of loan was approved but not being present at the meeting of the board of directors or a committee thereof at the time when it was approved, he

(i) being able to do so, filed with the company his protest against the unauthorized investment or loan $\ldots$ and

(ii) being able to do so, notified the Director, in writing, of that protest -..

\section{s. 15.2 Where}

(a) a death occurs without the attendance, of a physician in relation to the final illness of the deceased during the 14 days immediately preceeding the death. or

(b) the physician who attended the deceased is for any reason unable to complete the medical certificate referred to in section 15.1 within 48 hours of death,

the funeral director or the physician as the case may be shall ... notify a medical examiner who shall thereupon conduct an investi. gation into the death in accordance with $T$ The Fatility Inquiries Act. within 8 days after the date of that meeting.

within 24 hours after he became aware of it.

within 8 days after the date on which he filed his protest with the company.

forthwith 